\title{
Motivating Chinese employees of construction projects in Algeria
}

\author{
Merrah Hadjira \\ International Business School \\ Yunnan University of Finance and economics \\ Kunming, China \\ 2169602297@qq.com
}

\author{
Li Yan* \\ International Business School \\ Yunnan University of Finance and economics \\ Kunming, China \\ Cyliyan2002@163.com
}

\begin{abstract}
The globalization nowadays over the world has made the world a small global village where the domestic and international employees working together side by side in the same team, the international organizations depend on multinational teams created to achieve the organization objectives and challenges.
\end{abstract}

As result, today's global managers need to understand and apply effective motivation tools for their multinational teams. Motivation as the main tool to improve the performance of the employees became a challenging mission for the managers. Several studies and theories about motivation tried to identify the main factors for motivation, which can improve the performance of the employees and motivating people to perform with high productivity and affectivity. The theories came out of several motivation factors, this factors are classified differently or similarly from one theory to the other. But these theories all conducted in the west what made it inapplicable in other places in the world, or in multinational projects.

This study contains a literature review to the known theories and the current studies about motivating employees, and a brief literature review for the Islamic motivation for employees conducted in some Muslim countries.

Due to the diversity of the employee's culture and background, the motivation factors cannot have the same importance for all teamwork.

This research aims to understand the differences between motivating employees from two deferent nationalities and cultures in the same project, the study conducted the case of Chinese and Algerian employees working in construction projects in Algerian.

Keywords—motivation; Chinese employees; Chinese culture

\section{INTRODUCTION}

According to "China Africa research initiative" [1] Over than 227,407Chinese workers in Africa in 2016, the media speak about one million populations (2016 Sais Perspectives). In Algeria alone, there are 91596 Chinese workers (2016) as the first largest market for the Chinese companies especially the construction and infrastructure investment in Africa. In addition, the capital city Algiers has the only Chinatown in the Arab world.

*Corresponding author
Nowadays China state construction engineering corporation CSCEC is dominating the biggest projects in Algeria, for instance, the extension of Boumediene International Airport with Contract Value of USD 260 Million and the Grand Mosque, which will be the largest mosque in Africa with Contract Value of USD 1.5 Billion. Due to this big corporation and investment between Algeria and China this research aims to understand the factors motivate Algerian and Chinese to move for more understanding and partnering in the future.

Harrison and Lock [2] in their definition of Project management they mentioned people as the first factor to achieving projects objectives. Therefore forcing on what motivate and enhance the employee's productivity and performance one of the interesting subjects for managers and leaders of business today.

According to the PMBOK, project, HRM includes organizational planning, staff accusation, and team development. However, team development means training and motivation team members.

Tabassi, A.A., Ramli, M [3] said that "Motivation is a characteristic of an individual willing to expand efforts toward a particular set of behavior".

Motivating employees is the effective tool for high performance and one of the important factors for the project succeed the employee's individual performance can define the organizational performance, in other words, the effective use of motivation has a significant impact on the performance of employees and the overall success of a company. Steve Y. W. Lam and Conrad defined motivation as "Motivation is the driving force within individuals that compels them physiologically and psychologically to pursue one or more goals to fulfill their needs or expectations," [4].

However, as a human being the continuity of working in the same level of performance that the work needs it seems to be impossible without using the convenient motivation techniques. Therefore, this phenomenon of motivation was from a long time the research subject for several and continued studies and researchers.

Recently the managers are facing new challenges to motivate employees especially in multinational projects or overseas projects. As result of the diversity of culture and 
background that made motivation factors cannot be similar to all employees and if it is similar maybe is ranked differently.

The globalism and ability to adopt new values for some people makes the existing theories inapplicable in some cases according to Yang [5] who argue that "it is unlikely that jobs change people's temperaments they may well change their attitudes and beliefs", so even in the same teamwork motivation technique sometimes should be flexible to adopt the change of needs an behavior of the employees to motivation.

Therefore the Classical motivation theories are not enough to distinguish the common motivating factors for a small and diverse group of workers Robert \& Ankli [6], "Classical motivation literature becomes inadequate to address the new nature of work".

For a more deep understanding about this phenomenon, this study will conduct the importance and ranking of the motivation factors for a teamwork in Chinese construction projects in Algeria, the Chinese construction project contained Algerian and Chinese employees working side by side, the study will compare between the two different nationalities (which means two different cultures) and motivation factors.

In addition, the study will investigate what motivates Chinese employees working in Algeria. The previous studies focused on motivating Chinese employees working in China or in Europe but not workers in African countries.

Therefore the approach of motivating Chinese employees working in China and for those working in Algeria may not be the same, the change in the employee's environment or beliefs can lead to a change in their satisfaction and motivation factors and can be also related with the period spent in that different environment.

On the other hand, motivating Algerian employees as Muslim African Arab workers that have special Islamic ethics which can affect the style of motivation applied to them. Beside the Arabian and African culture and background.

\section{LITERATURE REVIEW}

There are several motivation theories that have shaped the management of human resources in organizations to achieve a motivated workforce, these theories digged deep to discover what lead to that people's behavior, and what is the factors and strategies that managers can follow to get the best performance and productivity of their employees.

Recently most of the studies have been conducted on the impact motivation factors and their classifications for different nationalities due to the globalization and the movement of human factors, but none have studied motivating multinational employees in projects within a country like Algeria, Algeria as a combination of several cultural elements which are African, Amazigh Arabic and the French colonize influence.

The motivation theories most of it were based on western societies the previews studies showed that Chinese employees in China are motivated differently, the motivation factors are classified completely deferent from the west.

Also, the previews study shown that culture, background, gender, education level and religion can define the most important factors for motiving employees.

Chinese working overseas for long period can change their behavior and priorities for motivation because of the crosscultural adjustment.

The theories and the previews studies about differences in culture and motivation theories tried to find how the researchers answer the question of the managers which is "how can I motivate my employees for best performance the work needs".

The extensive discussion and research in the human resources areas focused on motivating the employees to figure out the method can be used for employees high performance. There are several theorists tried to identify the main factors for motivation, which can improve the efficiently and effectively of the employees, in order to achieve the project objective in the planned time, cost and quality.

Motivation as one of the most important researched topics for human resources, theorists tried to find the appropriate approach to motivate employees, each theorist focused on one area or concept that seems crucial and essential. the variety of theories on motivation can be classed in two essential groups: The first group is the early content theories means "what motivate people?" and the Individual's needs that satisfied and motivated them, while The second group of theories is the contemporary theories: focus on "how to motivate people". There is no contradiction between the different theories but the managers can decide which approach can be suitable for their employees, the approach can be a combination of several theories Nyameh [7] mentioned that "The method an organization chooses for performance reviews and evaluations can have the biggest effect on employee performance"

A brief introduction of motivation theories is presented in this chapter in order to understand the historical researches about of employee motivation.

The group is the content theories means "what motivate people?" and the Individual's needs that satisfied and motivated them.

Maslow's hierarchy of needs, ERG motivation theory for Alderfer, McClelland's Human Motivation Theory and Herzberg's motivation factor theory. 


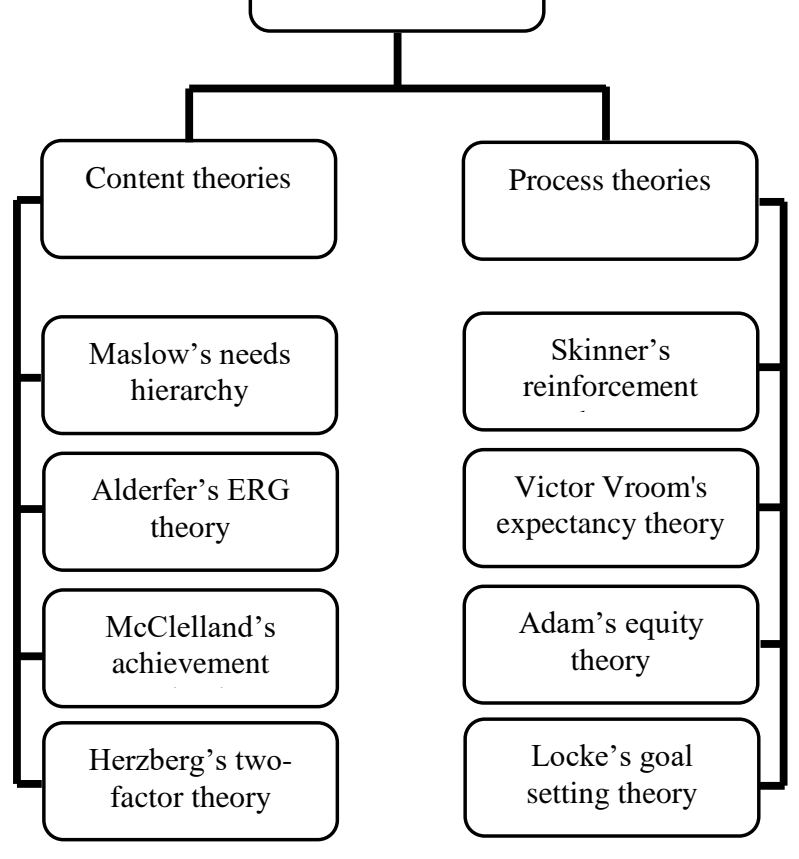

Fig. 1. The grouping of the motivation theories

\section{A. Content Theories}

First, Maslow's Human Needs Theory The need to have a personal feeling of wanting to get a certain thing and this feeling is usually accompanied by a sense of deprivation and tension and dissatisfaction and this is what prompts the person to seek to meet them through the required effort. Maslow saw that the Needs are the causes of every behavior and every human being has a number of needs.

The needs are categorized as: physiological needs are the highest priority of survival needs, followed by the needs of security, love, belonging, and then self-esteem, and thus we can draw them in the form of a hierarchy of priorities.

The ERG theory Clayton Alderfer in this theory, Alderfer focused on the needs as well as Maslow; In fact, his theory is revision to Maslow's needs theory and regrouping the need to three groups instead of five levels in a hierarchy. Alderfer grouped to needs for Existence, Relationships, and Personal Growth.

On 1961 David McClelland built on Maslow's work a new theory, He gave it to the world in his book "The Achieving Society." McClelland in the early reclassified the needs for human motivation into three, the need for achievement, need for power, and need for affiliation.

McClelland's Human Motivation Theory states that every person has one of three main driving motivators: the needs for achievement, affiliation, or power. These motivators are not inherent; we develop them through our culture and life experiences.

Herzberg two-factor Theory in 1959. Herzberg separates the motivation from the satisfaction and clarifies the relation between the nature and environment of work and the motivation factors. He divided the factors into motivation factors that motivate employees and hygiene or maintenance factors that satisfied them but don't posh them for high performance

As a conclusion, we can say that the content theories are not conserves but the contrary they have common factors that they share as it is concluded in the table below:

TABLE I. CONTENT THEORIES

\begin{tabular}{|c|c|c|c|}
\hline Maslow & Alderfer & McClelland & Herzberg \\
\hline Physiological & \multirow[b]{2}{*}{ Existence } & & \multirow{3}{*}{ Hygiene } \\
\hline $\begin{array}{l}\text { Safety and } \\
\text { security }\end{array}$ & & & \\
\hline $\begin{array}{l}\text { Belongingness } \\
\text { and love }\end{array}$ & Relatedness & $\begin{array}{l}\text { Need for } \\
\text { Affiliation }\end{array}$ & \\
\hline Self-esteem & \multirow[b]{2}{*}{ Growth } & $\begin{array}{l}\text { Need for } \\
\text { power }\end{array}$ & \multirow[b]{2}{*}{ Motivators } \\
\hline Self-actualization & & $\begin{array}{c}\text { Need for } \\
\text { achievemen } \\
t\end{array}$ & \\
\hline
\end{tabular}

Although the impact of applying the content theories in the workplace is very clear, the theories have been criticized in the managing human resources. In Ivory research [8] summary of the content theories as valid in terms of motivation at work because "the concept that people are driven by needs, seems to still be valid in terms of motivation at work" but the Content theories failed to demonstrate the process of motivating people because they try to answer the question of what motivate people, in fact, there is a great importance to answer the question of how to motivate people? This leads to the next set of theories process theories.

\section{B. Process theories}

The second group of theories is the process theories: focus on "How to motivate people"

The Reinforcement theory, based on Skinner's operant conditioning theory, says that behavior can be formed by its consequences [9].

The expectancy theory places an emphasis on the process and on the content of motivation as well, and it integrates needs, equity and reinforcement theories.

Victor Vroom's [10] expectancy theory aims to explain how people choose from the available actions. Vroom defines motivation as a process that governs our choices among alternative forms of voluntary behavior. The basic rationale of this theory is that motivation stems from the belief that decisions will have their desired outcomes. 
The equity theory states that people are motivated if they are treated equitably, and receive what they consider fair for their effort and costs.

The theory was suggested by Adams [11] and is based on Social Exchange theory.

According to this theory, people compare their contribution to work, costs of their actions and the benefits that will result to the contribution and benefits of the reference person. If people perceive that the ratio of their inputs-outputs to the ratio of referent other's input-output is inequitable, then they will be motivated to reduce the inequity.

The Goal setting theory by Locke's [12] is a model to integrate motivation close to the expectancy theory.

It is about setting and emplacing on specific and challenging performance goals; the motivation of the employees can be achieved by the commitment to these goals. Goals that can define the desired future; creating challenging goals can direct the behavior of the employees because the welling of accomplishing the goals motivates individuals better performance.

The motivation as one of the important factors for high performance was the subject of research of several theorists and scientist. Several theories as mentioned in the previews section conducted the needs and the processes that can motivate employees but the problem in this theories that all of is developed in the west.

The question asked by many researchers: Are all these western theories applicable in nonwestern countries? Are the personal characteristics main factor to determine the motivation approach?

Yang [5] investigated whether the motivation theories developed and applied in the west can apply in China, Yang explored that Chinese employees define and reclassify the known motivation factors differently. As result of this research, Yang found that good pay is the most important motivator for employees in Ningbo (Chinese city).

The researchers started to test the effect individual's differences even in the western society to find if the theories can be applied similarly to all employees or not, Kovach [13] imprecise that "Just as there are differences between what employees want over time, there may also be differences between categories of employees based on sex, age, income level, job type, and organization level".

Therefore a study in Malaysia for Rafikul \& Ahmad [14] investigated whether the western theories are applicable in Malaysia or not. The duo mentioned, "All the research findings that were applicable to the workers working in the Western countries may not be valid for the Malaysian workers". At the end of their research the fount that "monetary incentives play an important role in motivating Malaysian employees irrespective of gender, race, age group". This may be different in the current study of Chinese projects in Algeria. As Wiley [15] mentioned, "the strongest potential motivators are the things employees' value, but lack".
As religion is considered as part of the culture, there are some current studies about the relationship between Islamic ethics and principle and motivation. Hayati\& Caniago [16] conducted in their study "Islamic Work Ethic: The Role of Intrinsic Motivation, Job Satisfaction, Organizational Commitment and Job Performance" the result of their study was that "that the IWE directly affects intrinsic motivation"

But this study has it's limitation due to the sample chosen which cannot allowed us to generalize, also the study conducted in a bank that contain only Muslim workers as Hayati\& Caniago suggested that a comparison study between Muslim workers and non-Muslim, furthermore the personal characteristics in this study were ignored such as: religious background, age, and positions.

Bhatti et al. [17] saw that motivational theories tried to understand the factors that have a direct or indirect effect on motivation employees, but they argued that "these theories strongly rely on conventional principles based on western viewpoints of human needs and nature". Conversely, most of researchers ignored the cross-cultural and religious perspectives of employees.

Bhatti et al. think that from the Islamic perspective there are three motivation factors Spirituality, Punishment and Reward, and Justice

Spirituality: for Muslims spiritual motivation is very important which means all acts that they do is related spiritually to kind of worshiping Allah (God),

Punishment and Reward: Muslims believe that all acts are rewarded or punished, for Muslims, reward, and punishment is also related to the hereafter not only in this world.

\section{Justice:}

"O you who believe! Stand out firmly for justice, as witnesses to Allah, even though it be against yourselves, or your parents, or your kin, be he rich or poor, Allah is a Better Protector to both (than you). So follow not the lusts (of your hearts), lest you avoid justice, and if you distort your witness or refuse to give it, verily, Allah is Ever Well-Acquainted with what you do." (Quran, 4:135)

From this verse we can understand that justice is a very important factor in Muslim life not only at work because motivation level can increase in an environmental justice are established.

The study finished with a result of the three previews factors are "These three constructs appear to act more compellingly in improving the motivation of Muslim employees to succeed". The limitation of this study is that the sample used in this research is basically composed of old people from 13 respondents there are only 3 less than 40 years old, and 6 are above 50 years old which means that almost 50\% are old people, in this study the researchers also ignored the position of their respondents and their Work Experience. 


\section{ACTUAL STUDY}

The table below is conclusion of the study conducted in construction project for Chinese company in Algeria, the data collected through structured questionnaire.

TABLE II. STRUCTURED QUESTIONNAIRE

\begin{tabular}{|c|c|c|c|}
\hline Question & Nationality & $\mathrm{N}$ & Mean \\
\hline $\begin{array}{l}\text { I enjoy interacting with } \\
\text { people from different } \\
\text { cultures }\end{array}$ & $\begin{array}{l}\text { Algeria } \\
\text { China }\end{array}$ & $\begin{array}{l}93 \\
28\end{array}$ & $\begin{array}{l}3.99 \\
3.93\end{array}$ \\
\hline $\begin{array}{l}\text { I am confident that I can } \\
\text { socialize with locals in a } \\
\text { culture that is unfamiliar to } \\
\text { me }\end{array}$ & $\begin{array}{l}\text { Algeria } \\
\text { China }\end{array}$ & 93 & $\begin{array}{l}4.00 \\
3.89\end{array}$ \\
\hline $\begin{array}{l}\text { I am sure I can deal with } \\
\text { the stresses of adjusting to } \\
\text { a culture that is new to me }\end{array}$ & $\begin{array}{l}\text { Algeria } \\
\text { China }\end{array}$ & $\begin{array}{l}93 \\
28\end{array}$ & $\begin{array}{l}3.99 \\
3.46\end{array}$ \\
\hline $\begin{array}{l}\text { This work allows me for life } \\
\text { balance }\end{array}$ & $\begin{array}{l}\text { Algeria } \\
\text { China }\end{array}$ & $\begin{array}{l}93 \\
28 \\
\end{array}$ & $\begin{array}{l}2.13 \\
2.79 \\
\end{array}$ \\
\hline Working in flexible hours & $\begin{array}{l}\text { Algeria } \\
\text { China }\end{array}$ & $\begin{array}{l}93 \\
28 \\
\end{array}$ & $\begin{array}{l}1.87 \\
2.43 \\
\end{array}$ \\
\hline $\begin{array}{l}\text { I am pleased with the } \\
\text { career advancement } \\
\text { opportunities available to } \\
\text { me }\end{array}$ & $\begin{array}{l}\text { Algeria } \\
\text { China }\end{array}$ & 28 & $\begin{array}{l}2.65 \\
3.86\end{array}$ \\
\hline $\begin{array}{l}\text { I am satisfied with the job- } \\
\text { related training my } \\
\text { organization offers }\end{array}$ & $\begin{array}{l}\text { Algeria } \\
\text { China }\end{array}$ & $\begin{array}{l}93 \\
28\end{array}$ & $\begin{array}{l}3.05 \\
3.25\end{array}$ \\
\hline $\begin{array}{l}\text { I am inspired to meet my } \\
\text { goals at work }\end{array}$ & $\begin{array}{l}\text { Algeria } \\
\text { China } \\
\end{array}$ & $\begin{array}{l}93 \\
28 \\
\end{array}$ & $\begin{array}{l}3.59 \\
3.71 \\
\end{array}$ \\
\hline $\begin{array}{l}\text { I am determined to give my } \\
\text { best effort at work each } \\
\text { day }\end{array}$ & $\begin{array}{l}\text { Algeria } \\
\text { China }\end{array}$ & $\begin{array}{l}93 \\
28\end{array}$ & $\begin{array}{l}3.72 \\
4.00\end{array}$ \\
\hline $\begin{array}{l}\text { I am satisfied with the } \\
\text { culture of my workplace }\end{array}$ & $\begin{array}{l}\text { Algeria } \\
\text { China } \\
\end{array}$ & $\begin{array}{l}93 \\
28 \\
\end{array}$ & $\begin{array}{l}3.69 \\
3.79 \\
\end{array}$ \\
\hline $\begin{array}{l}\text { My organization is } \\
\text { dedicated to diversity }\end{array}$ & $\begin{array}{l}\text { Algeria } \\
\text { China } \\
\end{array}$ & $\begin{array}{l}93 \\
28 \\
\end{array}$ & $\begin{array}{l}3.85 \\
3.79 \\
\end{array}$ \\
\hline $\begin{array}{l}\text { I get excited about going to } \\
\text { work }\end{array}$ & $\begin{array}{l}\text { Algeria } \\
\text { China }\end{array}$ & $\begin{array}{l}93 \\
28 \\
\end{array}$ & $\begin{array}{l}3.66 \\
3.93 \\
\end{array}$ \\
\hline Communication between & Algeria & 93 & 4.23 \\
\hline
\end{tabular}

\begin{tabular}{|c|c|c|c|}
\hline $\begin{array}{l}\text { senior leaders and } \\
\text { employees is good }\end{array}$ & China & 28 & 3.39 \\
\hline $\begin{array}{l}\text { I am able to make } \\
\text { decisions affecting my } \\
\text { work }\end{array}$ & $\begin{array}{l}\text { Algeria } \\
\text { China }\end{array}$ & $\begin{array}{l}93 \\
28\end{array}$ & $\begin{array}{l}4.23 \\
3.25\end{array}$ \\
\hline $\begin{array}{l}\text { I am satisfied with my } \\
\text { overall compensation }\end{array}$ & $\begin{array}{l}\text { Algeria } \\
\text { China }\end{array}$ & $\begin{array}{l}93 \\
28\end{array}$ & $\begin{array}{l}1.62 \\
3.50\end{array}$ \\
\hline $\begin{array}{l}\text { Employees in my } \\
\text { organization take the } \\
\text { initiative to help other } \\
\text { employees when the need } \\
\text { arises }\end{array}$ & Algeria & 28 & 3.43 \\
\hline $\begin{array}{l}\text { I am satisfied with my } \\
\text { overall job security }\end{array}$ & $\begin{array}{l}\text { Algeria } \\
\text { China }\end{array}$ & $\begin{array}{l}93 \\
28 \\
\end{array}$ & $\begin{array}{l}3.70 \\
3.79 \\
\end{array}$ \\
\hline $\begin{array}{l}\text { My supervisor and I have a } \\
\text { good working relationship }\end{array}$ & $\begin{array}{l}\text { Algeria } \\
\text { China } \\
\end{array}$ & $\begin{array}{l}93 \\
28 \\
\end{array}$ & $\begin{array}{l}3.49 \\
3.89 \\
\end{array}$ \\
\hline $\begin{array}{l}\text { My organization safety } \\
\text { work environment } \\
\text { motivates me }\end{array}$ & $\begin{array}{l}\text { Algeria } \\
\text { China }\end{array}$ & $\begin{array}{l}93 \\
28\end{array}$ & $\begin{array}{l}3.52 \\
3.54\end{array}$ \\
\hline $\begin{array}{l}\text { I am satisfied with the } \\
\text { amount of paid leave } \\
\text { offered by my organization }\end{array}$ & $\begin{array}{l}\text { China } \\
\text { China }\end{array}$ & $\begin{array}{l}93 \\
28\end{array}$ & $\begin{array}{l}1.57 \\
3.93\end{array}$ \\
\hline $\begin{array}{l}\text { My coworkers and I have a } \\
\text { good working relationship }\end{array}$ & $\begin{array}{l}\text { Algeria } \\
\text { China } \\
\end{array}$ & $\begin{array}{l}93 \\
28 \\
\end{array}$ & $\begin{array}{l}3.91 \\
4.00 \\
\end{array}$ \\
\hline $\begin{array}{l}\text { I am satisfied with the } \\
\text { workplace flexibility offered } \\
\text { by my organization }\end{array}$ & $\begin{array}{l}\text { Algeria } \\
\text { China }\end{array}$ & $\begin{array}{l}93 \\
28\end{array}$ & $\begin{array}{l}3.26 \\
4.00\end{array}$ \\
\hline $\begin{array}{l}\text { I am satisfied with the } \\
\text { healthcare-related benefits } \\
\text { offered }\end{array}$ & $\begin{array}{l}\text { Algeria } \\
\text { China }\end{array}$ & $\begin{array}{l}93 \\
28\end{array}$ & $\begin{array}{l}2.92 \\
3.89\end{array}$ \\
\hline $\begin{array}{l}\text { How often do you consider } \\
\text { quitting your job? }\end{array}$ & $\begin{array}{l}\text { Algeria } \\
\text { China }\end{array}$ & $\begin{array}{l}93 \\
28\end{array}$ & $\begin{array}{l}2.67 \\
3.18\end{array}$ \\
\hline
\end{tabular}

The mean for used to compare the different between Algerian and Chinese worker in the project.

The result of the mean was quite similar except for some significant questions.

For instance working for flexible hours for the Algerian workers the mean was 1.87 which means that they disagree with is but for Chinese workers 2.43 which is quite neutral.

For the overall compensation also is significant difference 1.62 and 3.50 for Algerian and Chinese workers respectively. 


\section{CONCLUSION AND RECOMMENDATION}

As conclusion we can say that motivating Chinese and Algerian workers working in the same project is not that big different due to the similarities in some factors like the belonging and the needs for life balance, but is the same time there are some differences in some factors such as satisfaction about payment and security and safety at work.

For more understanding to the differences and similarities a study in the future with bigger sample can give a result that can be generalized.

\section{REFERENCES}

[1] China Africa Research Initiative (2018). Data: Chinese Workers in Africa [online] Available from: http://www.sais-cari.org/data-chineseworkers-in-africa/ [Accessed 30/03/2018]

[2] F. Harrison and D. Lock, Advanced Project Management: A Structured Approach. 4th edition. England: Grower Publishing Limited, 2004.

[3] A.A. Tabassi, M. Ramli, and A.H.A .Bakar, Training, motivation and teamwork improvement: The case of construction firms. African journal of business management, 2011, 5(14), p.5627.

[4] S. Lam. and C. Tang, C. Motivation of survey employees in construction projects. Journal of geospatial engineering, 2003, 5(1), pp.61-66.

[5] F. Yang. Work, motivation and personal characteristics: an in-depth study of six organizations in Ningbo. Chinese Management Studies, 2011, 5 (3), pp. $272-297$.

[6] R.E. Ankli, \& R. Palliam, Enabling a motivated workforce: exploring the sources of motivation. Development and Learning in Organizations: An International Journal, 2012, 26(2), 7-10.

[7] J. Nyameh, Application of the Maslow's hierarchy of need theory; impacts and implications on organizational culture, human resource and employee's performance. International Journal of Business and Management Invention, 2013, 2 (3), pp. $39-45$.

[8] Ivory Research, (2016). Theories of motivation: a critical evaluation of what they offer to practice. Available at
https://www.ivoryresearch.com/writers/imogen-cutting/[Accessed 31/03/2018].

[9] Skinner's Reinforcement Theory (2016) Available at: https://managementmania.com/en/skinners-reinforcement-theory

[10] P. Parijat, and S. Bagga, Victor Vroom's expectancy theory of motivation-An evaluation. International Research Journal of Business and Management, 2014, 7(9), pp.1-8.

[11] Adam's Equity Theory Available at: https://businessjargons.com/adamsequity-theory.html

[12] E.A. Locke, Motivation through conscious goal setting. Applied and preventive psychology, 1996, 5(2), pp.117-124.

[13] K.A. Kovach, What motivates employees? Workers and supervisors give different answers. Business Horizons, 1987, 30 (5), pp. 58 - 65.

[14] I. Rafikul. and Z.H.I. Ahmad, Employee motivation: a Malaysian perspective. International Journal of Commerce and Management, 2008, 18 (4), pp. $344-362$.

[15] C. Wiley, What motivates employees according to over 40 years of motivation surveys. International Journal of Manpower, 1997, 18 (3), pp. $263-280$.

[16] K. Hayati, and I. Caniago, Islamic Work Ethic: The Role of Intrinsic Motivation, Job Satisfaction, Organizational Commitment and Job Performance. Procedia - Social and Behavioral Sciences, 65, pp.272-277, 2012.

[17] O. Bhatti, U. Aslam, A. Hassan, and M. Sulaiman, Employee motivation an Islamic perspective. Humanomics, 2016, 32(1), pp.33-47. 